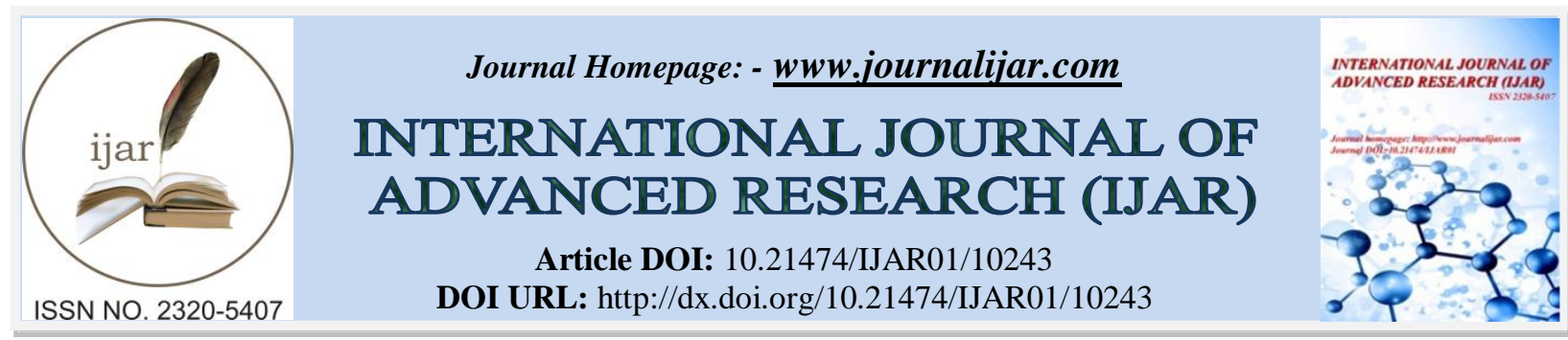

RESEARCH ARTICLE

\title{
CONDITIONS FAVORING SUCCESSFUL REINTERVENTION FOLLOWING LOWER LIMB GRAFT THROMBOSIS
}

\author{
Dr. Elancheralathan K. ${ }^{1}$ and Dr. Deepan Kumar B ${ }^{2}$ \\ 1. Department of Vascular Surgery, Tirunelveli Medical College and Hospital, Tirunelveli. \\ 2. Department of Vascular Surgery, Coimbatore Medical College and Hospital, Coimbatore.
}

\section{Manuscript Info}

….......................

Manuscript History

Received: 12 October 2019

Final Accepted: 14 November 2019

Published: December 2019

Key words:-

Lower Limb Ischemia, Reintervention, Graft Thrombosis

\section{Abstract}

Introduction: Postoperative graft thrombosis remains a significant clinical challenge. Etiologies are often multifactorial and include patient demographics, natural history, comorbidity conditions, and technical issues associated with arterial reconstruction. Here we analyze conditions favoring successful reintervention following lower limb graft thrombosis.

Material and Methods: This is an observational study done in twenty patients who underwent reintervention procedures for graft thrombosis. Indications for interventions were critical limb ischemia with rest pain / tissue loss and disabling claudication.

Results: Out of these twenty patients, post intervention patency rates were $60 \%$ (12 cases) and limb salvage rate were $70 \%$ (14 cases). Early intervention, claudicants and older patients had better patency and limb salvage in this study.

Conclusion: Thus conditions favoring successful reintervention following lower limb graft thrombosis were early intervention, claudicants and older patients.

Copy Right, IJAR, 2019,. All rights reserved.

\section{Introduction:-}

Postoperative graft thrombosis remains a significant clinical challenge. Etiologies are often multifactorial and include patient demographics, natural history, comorbidity conditions, and technical issues associated with arterial reconstruction $(1,2)$. Leg bypass for atherosclerotic femoral, popliteal, and tibial arterial lesions is being performed in increasing numbers in our aging population. Although prolonged patency and excellent limb salvage rates have become standard, $(1,2)$ vascular surgeons are inevitably encountering increasing numbers of patients with recurrent limb ischemia or recurrent graft stenosis after failed bypasses in the same leg. The outcome of a second leg bypass in patients with leg ischemia after failure of the first bypass has been the focus of numerous prior reports that have described marginally satisfactory limb salvage rates of $30 \%$ to $52 \%$ at 3 to 5 years in patients undergoing repeat operation(3,4,5). Here we analyze conditions favoring successful reintervention following lower limb graft thrombosis.

\section{Materials and Methods:-}

Study Design: It is a prospective observational study conducted in those patients who underwent reintervention for graft thrombosis following lower limb bypass surgeries in vascular surgery department during the year 2015-18 in Stanley medical college, Chennai.

Corresponding Author:- Dr. Elancheralathan K

Address:- Department of Vascular Surgery, Tirunelveli Medical College and Hospital, Tirunelveli. 
Proper history, thorough clinical examination and investigations in form CT angiogram were done to all patients. Inclusion: all patients who underwent reintervention procedures following graft thrombosis of lower limb bypasses like femoropopliteal/ femorodistal bypass were included. Both synthetic and vein graft thrombosis were taken into study.

\section{Exclusion:}

those underwent hybrid procedures, proximal interventions simultaneously like aortic/iliac interventions were excluded.

Follow-up: All the patients were followed-up via outpatient visits, following information was recorded at each visit: pulse palpation, ankle-brachial index (ABI) and symptoms. Average follow-up was 6 months

\section{Results and Discussion:-}

Vascular surgeons are encountering increasing numbers of patients with a failed or failing leg bypass graft in our aging population. Amputation in the presence of reconstructible vessels seems to be an especially unfavorable option. Compared with bypass it has an equal or greater mortality/morbidity rate coupled with an unacceptably large percentage of amputees who never regain bipedal status $(1,6)$.

Various factors were taken into consideration as potential risk /favorable factors, these are shown in table 1. These potential factors were compared in respect to post procedure patency and limb salvage.

Table 1:- Factors Taken For Consideration.

\begin{tabular}{|c|c|c|c|}
\hline S.NO & \multicolumn{2}{|l|}{ FACTORS } & NUMBER \\
\hline \multirow[t]{2}{*}{1} & \multirow[t]{2}{*}{ AGE IN YEARS } & $<50$ YEARS & 8 \\
\hline & & $>50$ YEARS & 12 \\
\hline \multirow[t]{2}{*}{2} & \multirow[t]{2}{*}{ GENDER } & MALE & 14 \\
\hline & & FEMALE & 6 \\
\hline 3 & \multicolumn{2}{|l|}{ SMOKERS } & 14 \\
\hline 4 & \multicolumn{2}{|l|}{ DIABETICS } & 8 \\
\hline \multirow[t]{2}{*}{5} & \multirow[t]{2}{*}{ ISCHEMIA SEVERITY } & CRITICAL LIMB & 12 \\
\hline & & CLAUDICANTS & 8 \\
\hline \multirow[t]{2}{*}{6} & \multirow{2}{*}{$\begin{array}{lr}\text { SYMPTOM } & \text { TO } \\
\text { INTERVENTION } & \\
\end{array}$} & EARLY < 1 WEEK & 7 \\
\hline & & LATE > 1 WEEK & 13 \\
\hline \multirow[t]{2}{*}{7} & \multirow[t]{2}{*}{ GRAFT THROMBOSIS } & EARLY < 1 MONTH & 9 \\
\hline & & LATE > 1 MONTH & 11 \\
\hline
\end{tabular}

Table 2:- Patency/ Limb Salvage With Respect To age.

\begin{tabular}{|c|l|l|l|l|}
\hline \multirow{2}{*}{ Age group } & Patency & Limb Salvage \\
\cline { 2 - 5 } & Patent & Occluded & Salvaged & Not Salvaged \\
\hline$<50$ years & $4 / 8(50 \%)$ & $4 / 8(50 \%)$ & $5 / 8(62.5 \%)$ & $3 / 8(37.5 \%)$ \\
\hline$>50$ years & $9 / 12(75 \%)$ & $3 / 12(25 \%)$ & $10 / 12(83.3 \%)$ & $2 / 12(16.7 \%)$ \\
\hline
\end{tabular}

Patients with higher age group had higher patency of $75 \%$ against $50 \%$ for less than 50 years of age. These show older age people having atherosclerotic lesions has good result in following reintervention when compared to younger age individuals with smoking, vasculitis and hypercoaguable conditions for etiology $(5,6)$.

Table 3:- Patency/ Limb Salvage With Respect To Timing Of Intervention.

\begin{tabular}{|l|l|l|l|l|}
\hline Timing Of Intervention From & Patency & Limb Salvage \\
\cline { 3 - 5 } Symptom Onsent & Patent & Occluded & Salvaged & Not Salvaged \\
\hline Early <1 week & $6 / 7(85 \%)$ & $1 / 7(15 \%)$ & $6 / 7(85 \%)$ & $1 / 7(15 \%)$ \\
\hline Late $>1$ week & $6 / 13(46 \%)$ & $7 / 13(54 \%)$ & $8 / 13(61.5 \%)$ & $5 / 13(38.5 \%)$ \\
\hline
\end{tabular}


Patients who presented early to hospital following symptom onset from graft thrombosis were benefitted well because of good results of graft thrombectomy / thrombolysis in fresh thrombosis before getting organized. Also shorter ischemic duration always has better outcome in means of patency and limb salvage(7).

Table 4:- Patency/ Limb Salvage With Respect To ischemia severity.

\begin{tabular}{|l|l|l|l|l|}
\hline \multirow{2}{*}{ Ischemia Severity } & \multicolumn{3}{l|}{ Patency } & Limb Salvage \\
\cline { 2 - 5 } & Patent & Occluded & Salvaged & Not Salvaged \\
\hline claudicant & $6 / 8(75 \%)$ & $2 / 8(25 \%)$ & $7 / 8(87.5 \%)$ & $1 / 8(12.5 \%)$ \\
\hline Critical limb ischemia & $6 / 12(50 \%)$ & $6 / 12(50 \%)$ & $7 / 13(53.8 \%)$ & $6 / 13(46.2 \%)$ \\
\hline
\end{tabular}

As expected patients with less severe ischemia inform of claudication had better patency and limb salvage of $75 \%$ and $87.5 \%$ respectively. Thus critical limb ischemia patients with poor collaterals and severe ischemia require more urgent and extensive interventions for limb salvage(7).

\section{Conculsion:-}

Thus conditions favoring successful reintervention following lower limb graft thrombosis were early intervention, claudicants and older patients. These group of individuals has better patency and limb salvage rates.

\section{References:-}

1. Rutherford's vascular surgery, volume-1-2, $9^{\text {th }}$ edition.

2. Wesley S.Moore's Vascular and Endovascular surgery, $8^{\text {th }}$ edition

3. Taylor LM Jr, Hamre D, Dalman RL, Porter JM. Limb salvage vs amputation for critical ischemia: The role of vascular surgery. Arch Surg 1991;126:1251-8.

4. Veith FJ, Gupta SK, Samson RH, et al. Progress in limb salvage by reconstructive arterial surgery combined with improved adjunctive procedures. Ann Surg 1981;194:386- 401.

5. Green RM, Ouriel K, Ricotta n, et al. Revision of failed infrainguinal bypass graft: principles of management. Surgery 1986; 1 00:646-53.

6. Harris RW, Andros G, Salles-Cunha SX, et al. Totally autogenous venovenous composite bypass grafts. Arch Surg 1986;121:1128-32.

7. Harris RW, Andros G, Salles-Cunha SX, et al. Alternative autogenous vein grafts to the inadequate saphenous vein. Surgery 1986;100:822-7. 